\title{
Small Molecular Weight Compounds Antagonistic to Amyloid Peptide25-35
}

\author{
W. Robert Williams \\ Faculty of Life Sciences \& Education, University of South Wales, Cardiff, UK \\ Email: Robert.williams2@southwales.ac.uk
}

How to cite this paper: Williams, W.R (2021) Small Molecular Weight Compounds Antagonistic to Amyloid Peptide 25-35. Journal of Biosciences and Medicines, 9, 41-51. https://doi.org/10.4236/jbm.2021.91004

Received: December 8, 2020

Accepted: January 18, 2021

Published: January 21, 2021

Copyright $\odot 2021$ by author(s) and Scientific Research Publishing Inc. This work is licensed under the Creative Commons Attribution International License (CC BY 4.0).

http://creativecommons.org/licenses/by/4.0/

\begin{abstract}
High levels of the neurotoxic beta-amyloid protein $(\mathrm{A} \beta)$ in patients with Alzheimer's disease present a significant therapeutic target, although the protein is unlikely to be the sole instigator of this condition. $\mathrm{A} \beta$ initiates cell receptor and synapse dysfunction, and causes mitochondrial damage within neurons. Neurotransmitters and various small molecular weight compounds ameliorate the effects of $\mathrm{A} \beta$ on cell membranes. This study uses a molecular modeling technique to compare the structures of $\mathrm{A} \beta_{25-35}$ and compounds known to antagonize properties of the polypeptide. Compounds provide good fits to the peptide amino acid residues, revealing planarity in their linear structures and fitting points. Compounds and polypeptide share relative molecular similarity, affinity for receptors and apoptosis modulating properties indicative of their potential for competition at neuron membrane sites. The therapeutic targeting of $\mathrm{A} \beta$ by small molecular weight compounds may benefit from a multi-drug approach.
\end{abstract}

\section{Keywords}

Alzheimer's Disease, Beta-Amyloid Peptide, Beta-Amyloid Antagonists, Molecular Modeling

\section{Introduction}

In past decades, beta-amyloid protein $(\mathrm{A} \beta)$ has been a main focus of diagnostic and therapeutic strategies seeking to prevent the histological and neurochemical changes of Alzheimer's disease (AD) [1]. The 40 or more amino acid residues of $\mathrm{A} \beta$ contribute to an intrinsically disordered protein with changes in folding and conformation dependent on binding ligands and environment [2]. $\mathrm{A} \beta$ self-assembles on cell membranes disrupting receptor function and promoting the development of ion permeable pores [3] [4]. The resulting neurocytotox- 
icity is manifest as oxidative-stress, changes in cell calcium and apoptosis [5]. Several classes of cell receptor are susceptible to desensitization, internalisation or activation by $\mathrm{A} \beta$ : adrenergic, NMDA and $\alpha 7$-nicotinic acid $(\alpha-7 \mathrm{nACh})$ receptors [5] [6]. $\mathrm{A} \beta$ fragment $\mathrm{A} \beta_{25-35}$, the biologically active region of $\mathrm{A} \beta$, also inhibits glucose uptake in hippocampal neuron cultures via activation of Gs-protein coupled receptors [7].

The perceived role of $\mathrm{A} \beta$ in the causation of $\mathrm{AD}$ is currently more equivocal, as informed by a more recent body of experimental work on mouse models and the ineffectiveness of anti-amyloid therapies [8] [9]. A $\beta$ may have a functional role in the brain, as it demonstrates concentration dependent beneficial effects on $\alpha$-7nACh and NMDA receptors [10]. Picomolar concentrations of oligomeric $\mathrm{A} \beta$ modulate pre- and post-synaptic mechanisms, augmenting neurotransmitter release and facilitating early to late long-term potentiation (LTP) transition via $\alpha 7$-nAchR and the NO/cGMP pathway [11]. This more favourable view of $\mathrm{A} \beta$ complements the knowledge that platelets are a major source of amyloid precursor protein [12]. Amyloid fibril formation is a generic property of proteins, including $\beta_{2}$-microglobulin and proteins present in foods [13] [14].

There are endogenous defence mechanisms against the neurotoxicity of $\mathrm{A} \beta$. $\alpha-7 \mathrm{nAChRs}$ are neuroprotective in regard to amyloid accumulation, cognitive decline and pathology in mice [15]. Insulin is one of several growth factors with impaired signaling in $\mathrm{AD}$ that provides protection following correction of its deficit in hippocampal neurons [16]. Steroids and cyclic nucleotides also have a role in regulating the toxicity of $A \beta$. Allopregnanolone restores learning and memory function in mice and reduces $\mathrm{A} \beta$ burden [17]. cAMP ameliorates $\mathrm{A} \beta$ induced memory impairment and hippocampal mitochondrial dysfunction in rats [18]. Studies in mice demonstrate a degree of interaction between $\mathrm{A} \beta$ and cGMP; down-regulation of cGMP signaling by $\mathrm{A} \beta$, and cGMP enhancement of $\mathrm{A} \beta$ levels with positive effects on synaptic plasticity and memory [19]. Two studies on $\mathrm{AD}$ patients have reported reduced cerebrospinal fluid levels of cGMP (but not cAMP) in association with cognitive decline and amyloid pathology [20] [21].

Several drugs and natural products are known to interfere with the self-assembly and toxicity of A $\beta$. Doxocyclin [13], curcumin [22], resveratrol [23] and ibuprofen [24] are aggregation inhibitors of amyloid peptide and fibril formation. Tromethamine [25], valproic acid [26], cinnamaldehyde [27], vitamin E [28] and gallic acid [29] reduce the toxicity of $\mathrm{A} \beta_{25-35}$. Docosahexaenoic acid, genistein and folic acid protect against $\mathrm{A} \beta_{25-35}$-induced apoptosis [30] [31]. There is also epidemiologic evidence for delayed onset AD attributable to the use of NSAIDs [32]. Of pertinence to this study are observations that the above small molecular weight compounds modulate cell apoptosis and induce oxidative stress irrespective of the presence of $\mathrm{A} \beta$ [33]. This study uses a molecular modeling approach to report on molecular similarity within these compounds and the amino acid residues of $\mathrm{A} \beta_{25-35}$. The results are relevant to the interaction of $\mathrm{A} \beta$ with cell 
membrane receptors and antagonism of neurotoxicity by small molecular weight compounds.

\section{Methods}

The molecular structure and conformation of $\mathrm{A} \beta_{25-35}$ is basedon the model given by Song [34]. The Nemesis software program (Oxford Molecular version 2.1) is used to build molecular structures from contents of the program fragment file and minimise the structures by conformational analysis. The compound structures are minimum energy conformers in an uncharged form, whereas polypeptide $\mathrm{A} \beta_{25-35}$ is a partially minimised structure. The computational program fits paired molecular structures of the compounds and $\mathrm{A} \beta_{25-35}$ on a three-point basis. Fitting points comprise of atoms of similar type and partial charge within compound and $\mathrm{A} \beta_{25-35}$ structures, identified in the figures with respect to the amino acid labels. Compound colour-coded atoms in the figures identify ligand-fitting points: carbon-green, nitrogen-blue, oxygen-red. To improve on presentation, bond order within the molecular structures is not shown and in some fits of the compounds the $\mathrm{A} \beta_{25-35}$ structure is cropped. The Nemesis program computes goodness-of-fit values, in respect of inter-atomic distance at each fitting point and root mean square (RMS) value.

\section{Results}

Compound fitting points are identified in Figure 1 and Figure 2 and the fitting data are given in Table 1. Neurotransmitter structures of NMDA, tromethamine and the $\alpha 7$-nAchR agonist TC-1698 fit to one amino acid residue (Figure 1). The structures of silibinin and cinnamaldehyde fit across two, whereas pregnenolone and folic acid fit across three residues (Figure 2). A second fit of NMDA to isoleucine residues is also given (Figure 1(i)). The fitting points of most compounds include a peptide bond carbonyl group, whereas nitrogen species are involved in the fit of folic acid. Several compounds fit to the same amino acid residues: cinnamaldehyde and gallic acid, NMDA and docosahexaenoic acid, ibuprofen and 17- $\beta$ estradiol, folic acid and FDDNP

(2-[1-[6-[2-fluroethyl(methyl)amino]napthalen-2-yl]ethylidene]propanedinitrile (a radiopharmaceutical used to disclose aggregates of $\mathrm{A} \beta$ and tau) [1]. Valproic acid alone fits to methionine 35 . The linear and planar dispositions of compound fitting points, evident within the figures, sometimes form part of a fused cyclic ring system as in doxycycline, 17-beta estradiol and pregnenolone. Comparative values for the compounds demonstrate good quality fits with interatomic distances of $0.16 \AA$ or less, and RMS values $<0.0300 \AA$.

\section{Discussion}

Of approximately 100 agents currently in $\mathrm{AD}$ modification trials, $40 \%$ target amyloid and almost half are small molecular weight compounds [35]. Pharmacologic strategies that target intrinsically disordered proteins include disaggregation, 
Table 1. Fitting data of compounds and $\beta$-amyloid an-35 $_{25}$ peptide.

\begin{tabular}{|c|c|c|c|c|}
\hline Compound & $\begin{array}{l}\text { Amino acid } \\
\text { residues }\end{array}$ & $\begin{array}{l}\text { Fitting } \\
\text { points }\end{array}$ & $\begin{array}{c}\text { Interatomic } \\
\text { distances }(\AA)\end{array}$ & RMS $(\AA)$ \\
\hline Tromethamine & S26 & $\mathrm{O} 2 \mathrm{C} 2 \mathrm{O} 1$ & $0.05,0.03,0.05$ & 0.0134 \\
\hline Cinnamaldehyde & $\mathrm{I} 32, \mathrm{G} 33$ & $\mathrm{O} 1 \mathrm{C} 1, \mathrm{C} 1^{\prime}$ & $0.08,0.04,0.10$ & 0.0074 \\
\hline NMDA & $\mathrm{N} 27$ & $\mathrm{C} 1 \mathrm{C} 2 \mathrm{C} 4$ & $0.03,0.04,0.02$ & 0.0093 \\
\hline NMDA & $\mathrm{I} 32, \mathrm{I} 31$ & $\mathrm{C} 1$ ', $\mathrm{C} 1 \mathrm{O} 1$ & $0.10,0.10,0.01$ & 0.0050 \\
\hline TC-1698 & I31 & $\mathrm{C} 1 \mathrm{C} 2 \mathrm{C} 3$ & $0.03,0.04,0.06$ & 0.0054 \\
\hline Ibuprofen & $\mathrm{I} 32, \mathrm{~L} 34$ & $\mathrm{O} 1 \mathrm{C} 1, \mathrm{C} 4$ & $0.04,0.07,0.05$ & 0.0043 \\
\hline Gallic acid & $\mathrm{I} 32, \mathrm{G} 33$ & $\mathrm{O} 1 \mathrm{C} 1, \mathrm{C} 1^{\prime}$ & $0.08,0.05,0.07$ & 0.0093 \\
\hline Doxycyline & K28, N27 & $\mathrm{Cl}^{\prime}, \mathrm{C} 1 \mathrm{C} 4$ & $0.09,0.11,0.07$ & 0.0261 \\
\hline Valproic acid & M35 & $\mathrm{O} 1 \mathrm{C} 1 \mathrm{C} 2$ & $0.01,0.01,0.01$ & 0.0022 \\
\hline Silibinin & I32, L34 & $\mathrm{O} 1 \mathrm{C} 1, \mathrm{C} 1^{\prime}$ & $0.05,0.14,0.12$ & 0.0050 \\
\hline Docosahexaenoic acid & $\mathrm{I} 31, \mathrm{I} 32$ & $\mathrm{C} 2 \mathrm{C} 1, \mathrm{C} 1^{\prime}$ & $0.09,0.14,0.12$ & 0.0116 \\
\hline Vitamin E & G33, L34 & $\mathrm{O} 1, \mathrm{C} 2 \mathrm{C} 1$ & $0.03,0.10,0.10$ & 0.0051 \\
\hline $17-\beta$ Estradiol & I32, L34 & $\mathrm{O} 1 \mathrm{C} 1, \mathrm{Cl}{ }^{\prime}$ & $0.06,0.12,0.06$ & 0.0065 \\
\hline cGMP & $\mathrm{K} 28, \mathrm{~A} 30$ & $\mathrm{O} 1 \mathrm{C} 1, \mathrm{C} 1$ & $0.02,0.04,0.06$ & 0.0004 \\
\hline Genistein & I31, L34 & $\mathrm{C} 2 \mathrm{C} 1, \mathrm{C} 2{ }^{\prime}$ & $0.08,0.07,0.03$ & 0.0053 \\
\hline Curcumin & A30, G33 & $\mathrm{C} 2 \mathrm{C} 1, \mathrm{C} 1{ }^{\prime}$ & $0.15,0.16,0.02$ & 0.0124 \\
\hline Pregnenolone & $\mathrm{I} 31, \mathrm{I} 32, \mathrm{G} 33$ & $\mathrm{C} 1 \mathrm{C} 2 \mathrm{C} 1^{\prime}$ & $0.04,0.05,0.06$ & 0.0027 \\
\hline Folic acid & L34, G33, I32 & N1C1N1' & $0.11,0.08,0.08$ & 0.0108 \\
\hline FDDNP & L34, G33, I32 & $\mathrm{C} 2 \mathrm{C} 1 \mathrm{C} 1 '$ & $0.06,0.03,0.04$ & 0.0118 \\
\hline Cromoglycate-conformer & G29, L34 & $\mathrm{C} 1 \mathrm{O} 1, \mathrm{C} 1^{\prime}$ & $0.11,0.13,0.02$ & 0.0053 \\
\hline
\end{tabular}

Compound molecular structures are superimposed and fitted individually to labeled amino acid residues of the peptide model (see Figure 1) by the molecular modeling program, generating fitting data and goodness of fit values.

and the promotion of a stable or non toxic species of amyloid protein [2]. Results from this study indicate that a planar pharmacophore incorporating oxygen-rich groups may afford a structural basis for the design of new compounds with the potential to interact with $\mathrm{A} \beta$. Both features are present within a high energy cromoglycate conformer ( $2.5 \mathrm{kcal}$ of free energy, Figure 2$)$ but not in the folded minimum energy state conformer (not shown). The affinity of the compounds for different amino acid residues within $\mathrm{A} \beta_{25-35}$ suggests that therapeutic targeting of $\mathrm{A} \beta$ may benefit from a multi-drug approach.

In regard to physiological properties of the investigated compounds, cinnamaldehyde reduces $\mathrm{A} \beta$-induced toxicity in a neuronal cell line by interacting with adenosine and NMDA receptors [27]. Valproic acid and curcumin demonstrate neuroprotective properties against $\mathrm{A} \beta_{25-35}$-induced oxidative damage and apoptosis in PC12 cell cultures [26] [36]. Docosahexaenoic acid and vitamin E have a synergistic effect in antagonising oxidative damage in PC12 cells induced 
a
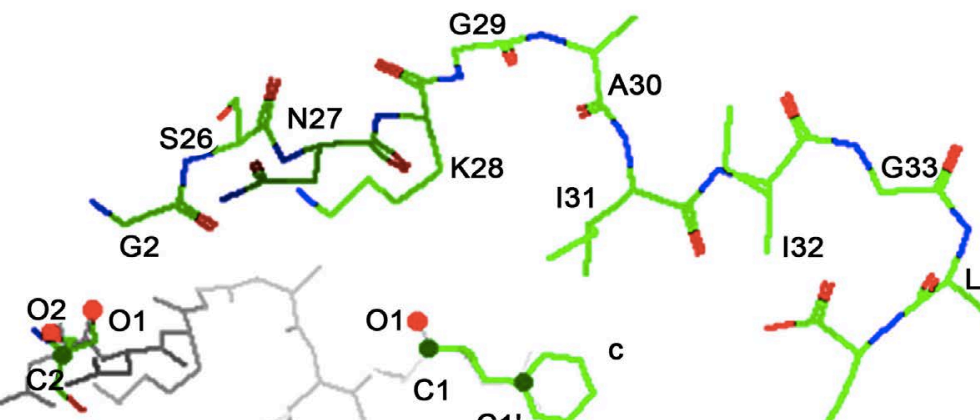

1

019

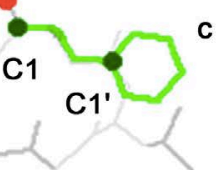

c<smiles>C1CCCCC1</smiles>

\section{.}

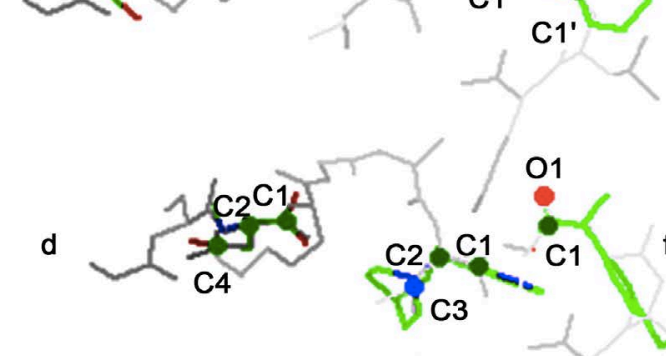

e
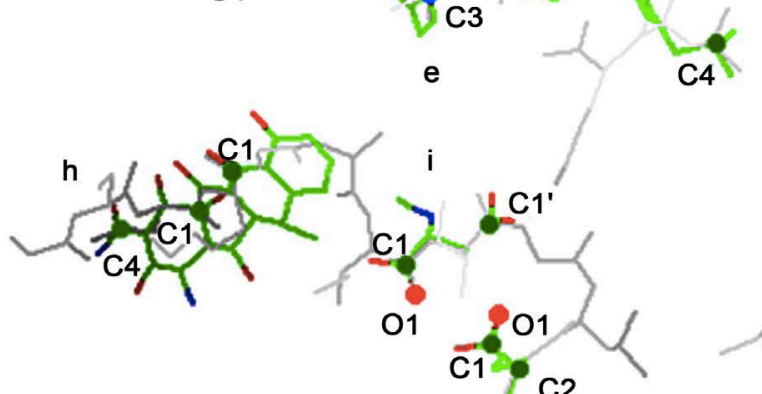

C4
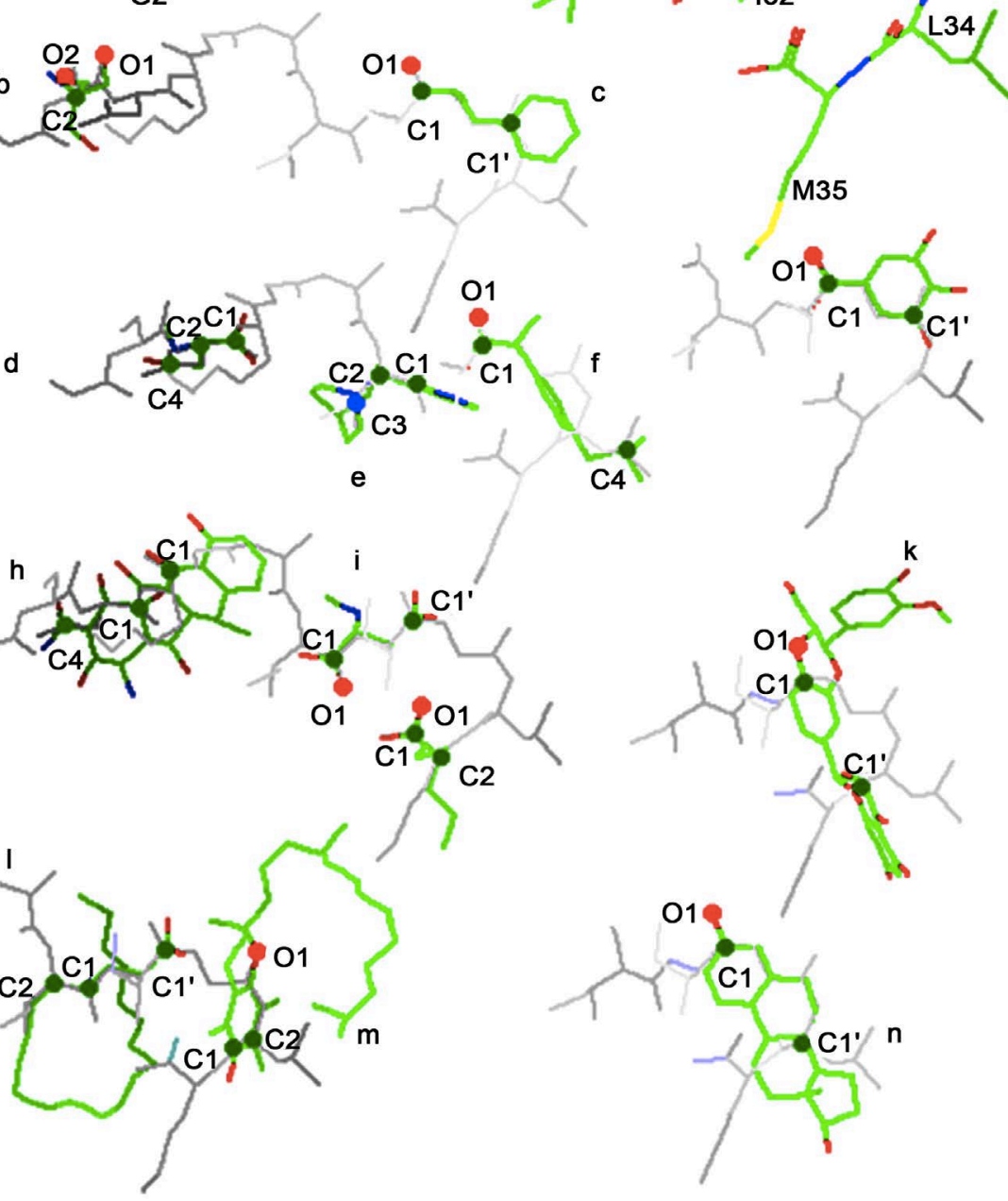

Figure 1. a Molecular model of $\mathrm{A} \beta_{25-35}$ peptide with labeled amino acid residues: G-glycine, $\mathrm{S}$-serine, $\mathrm{N}$-asparagine, K-lysine, A-alanine, I-isoleucine, L-leucine, M-methionine. b-n Fits of compound structures to labeled fitting points of $\mathrm{A} \beta_{25-35}$ peptide model(grey): carbon (green), nitrogen (blue), oxygen (red). $\mathbf{b}$ tromethamine, c cinnamaldehyde, $\mathbf{d}$ NMDA, $\mathbf{e}$ TC-1698, $\mathbf{f}$ ibuprofen, $\mathbf{g}$ gallic acid, $\mathbf{h}$ doxycyline, $\mathbf{i}$ NMDA, $\mathbf{j}$ valproic acid, $\mathbf{k}$ silibinin, $\mathbf{l}$ docosahexaenoic acid, $\mathbf{m}$ vitamin $\mathrm{E}, \mathrm{n}$ 17-beta estradiol.

by $\mathrm{A} \beta_{25-35}$ [28]. The inhibitory action of silibinin on ROS, induced by $\mathrm{A} \beta$ in a rat $\beta$-cell line, is attributed to up-regulation of estrogen receptor signaling [37]. Gallic acid improves spatial learning and memory in mice by disrupting $\mathrm{A} \beta_{25-35}$ aggregation [29]. The destructive effects of doxycycline on amyloid fibril formation and cytotoxicity have been investigated using the $\beta 2$-microglobulin protein [13]. Ibuprofen benefits the hippocampal region in rat brain by restoring $\mathrm{A} \beta$ impairment of the cGMP pathway and synaptic expression [24] [38]. Pregnenolone (but not the sulphate ester) provides protection against $\mathrm{A} \beta_{25-35}$ toxicity in 


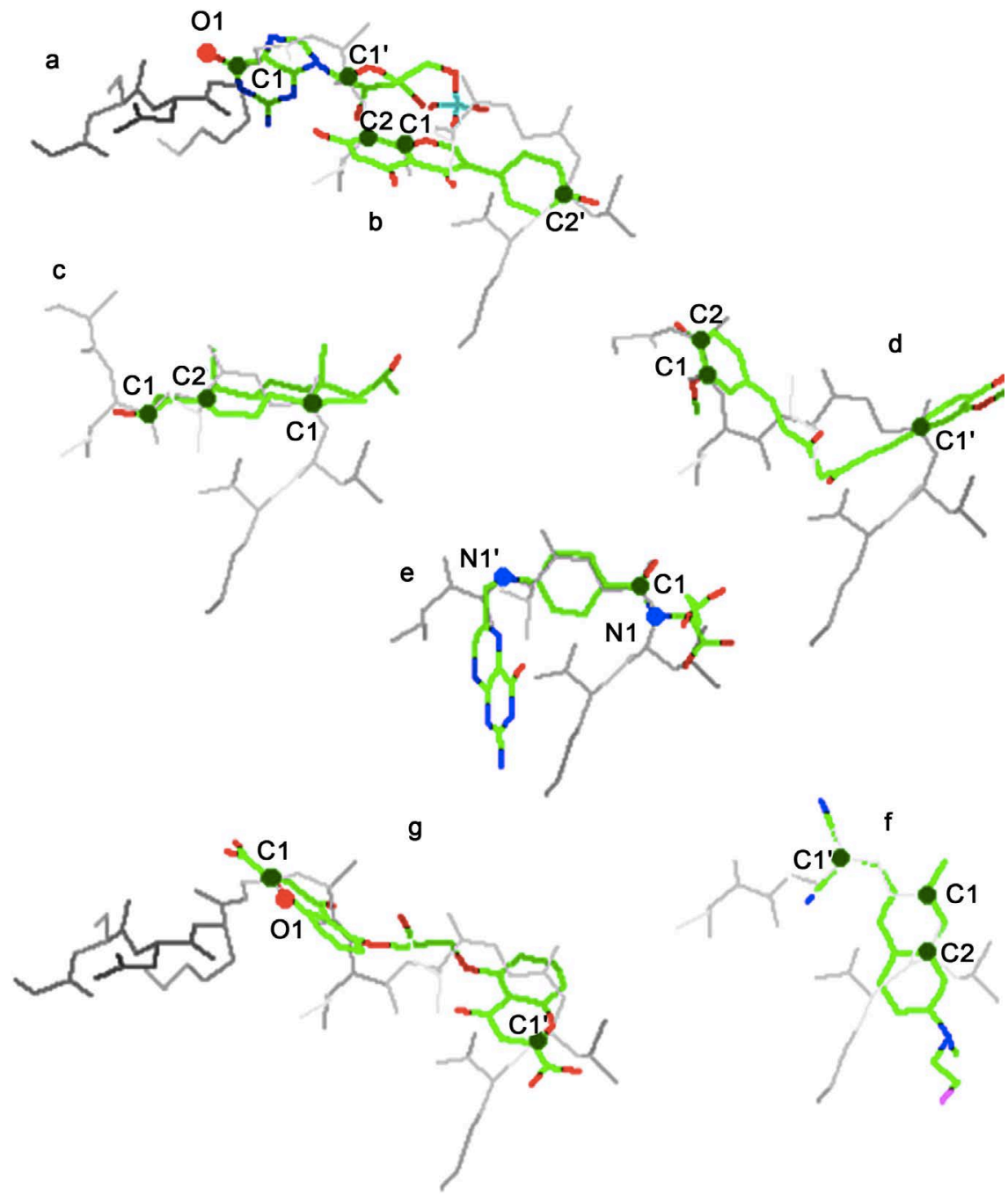

Figure 2. a-g Fits of compound structures to labeled fitting points of $A \beta_{25-35}$ peptide model (grey): carbon (green), nitrogen (blue), oxygen (red). a cGMP, b genistein, c pregnenolone, $\mathbf{d}$ curcumin, $\mathbf{e}$ folic acid, f FDDNP, $\mathbf{g}$ cromoglycate conformer.

PC-12 cell cultures [39]. In AD patients, pregnenolone sulphate and DHEAS levels are significantly reduced and correlate negatively with $\mathrm{A} \beta[40]$.

The changes within brain structure that produce the toxic environment and pathogenesis characteristic of $\mathrm{AD}$ are becoming more apparent. Reduced neurotransmitter and steroid levels are evident in $\mathrm{AD}$ patients and reported reductions in cyclic nucleotide synthesis may relate to these deficits, leading to loss of synapse function and neuron depletion [41] [42]. The normal G-protein cell cycle regulation of physiologic processes, responsive to neurotransmitters, cyclic nucleotides and steroid action, is diminished and superseded by abnormal ROS generation, amyloid production and cell apoptosis. Abnormalities within cell organelles, mitochondria and endoplasmic reticulum point to disordered metabolism and oxidative deficits. $\mathrm{A} \beta$ accumulates within mitochondria and inhibits processes within the respiratory chain [43]. Excess nitric oxide and reactive species of nitric oxide within mitochondria contribute to mitochondrial malfunction and neu- 
ronal cell death [44]. The endoplasmic reticulum contributes to ROS production through the generation of disulphide bonds during protein-folding and -misfolding processes [45].

In the absence of pharmacologic intervention for $\mathrm{AD}$, physical activity may prevent the decline in cognitive function, through assisting cerebral blood flow, neurogenesis and up-regulating neurotransmitter activity [46] [47]. Increases in synaptic activity and receptor expression protect against $\mathrm{A} \beta$-associated impairment of synapse function [16] [48]. The population density of plasma membrane NMDA and AMPA receptors regulates the dysfunctional effects of $A \beta$ at hippocampal neuron synapses [49] [50]. Deficits in neurotransmitter-targeted receptors facilitate the binding of $\mathrm{A} \beta$ to cell membrane receptors and internal access to cells [51].

$\mathrm{A} \beta_{25-35}$ and the investigated compound structures share an affinity for cell membrane receptors, apoptosis modulation and relative molecular similarity. Although there are several compounds that reduce the toxic and apoptotic properties of $\mathrm{A} \beta$, the focus should perhaps be on the function of the brain's endogenous steroids and cyclic nucleotides that contribute to this role in healthy individuals. In consideration of the available evidence for the functional roles of $\mathrm{A} \beta$ in neuronal and haemodynamic regulation, the initiation of apoptosis by $\mathrm{A} \beta$ may also be a natural function of this protein, targeting neurons with deficits in agonist and synaptic activity; eliminating cells that are no longer functional.

\section{Conflicts of Interest}

The author declares no conflicts of interest regarding the publication of this paper.

\section{References}

[1] Rodrigue, K.M., Kennedy, K.M. and Park, D.C. (2009) Beta-Amyloid Deposition and the Aging Brain. Neuropsychology Review, 19, Article No. 436. https://doi.org/10.1007/s11065-009-9118-x

[2] Martinelli, A.H.S., Lopes, F.C., John, E.B.O., Carlini, C.R. and Ligabue-Braun, R. (2019) Modulation of Disordered Proteins with a Focus on Neurodegenerative Diseases and Other Pathologies. International Journal of Molecular Sciences, 20, 1322. https://doi.org/10.3390/ijms20061322

[3] Lal, R., Lin, H. and Quist, A.P. (2007) Amyloid Beta Ion Channel: 3D Structure and Relevance to Amyloid Channel Paradigm. Biochimica et Biophysica Acta, 1768, 19661975. https://doi.org/10.1016/j.bbamem.2007.04.021

[4] Kaminsky, Y.G., Marlatt, M.W., Smith, M.A. and Kosenko, E.A. (2010) Subcellular and Metabolic Examination of Amyloid- $\beta$ Peptides in Alzheimer Disease Pathogenesis: Evidence for A $\beta_{25-35}$. Experimental Neurology, 221, 26-37. https://doi.org/10.1016/j.expneurol.2009.09.005

[5] Zhao, L.N., Long, H.W., Mu, Y. and Chew, L.Y. (2012) The Toxicity of Amyloid $\beta$ Oligomers. International Journal of Molecular Sciences, 13, 7303-7327. https://doi.org/10.3390/ijms13067303

[6] Wang, D., Yuen, E.Y., Zhou, Y., Yan, Z. and Xiang, Y.K. (2011) Amyloid Beta Pep- 
tide-(1-42) Induces Internalization and Degradation of beta2 Adrenergic Receptors in Prefrontal Cortical Neurons. Journal of Biological Chemistry, 26, 31852-31863. https://doi.org/10.1074/jbc.M111.244335

[7] Prapong, T., Uemura, E. and Hsu, W.H. (2001) G Protein and cAMP-Dependent Protein Kinase Mediate Amyloid Beta-Peptide Inhibition of Neuronal Glucose Uptake. Experimental Neurology, 167, 59-64. https://doi.org/10.1006/exnr.2000.7519

[8] Skaper, S.D. (2012) Alzheimer's Disease and Amyloid: Culprit or Coincidence? International Review of Neurobiology, 102, 277-316. https://doi.org/10.1016/B978-0-12-386986-9.00011-9

[9] Kosiov, S., Afonin, A., Evsyukov, L. and Bondarenko, A. (2017) Alzheimer's Disease: As It Was in the Beginning. Reviews in the Neurosciences, 28, 825-843. https://doi.org/10.1515/revneuro-2017-0006

[10] Brothers, H.M., Gosztyla, M.L. and Robinson, S.R. (2018) The Physiological Roles of Amyloid- $\beta$ Peptide Hint at New Ways to Treat Alzheimer's Disease. Frontiers in Aging Neurosciences, 10, 118. https://doi.org/10.3389/fnagi.2018.00118

[11] Gulisano, W., Melone, M., Ripoli, C., Tropea, M.R., Li Puma, D.D., Giunta, S., Cocco, S., Marcotulli, D., Origlia, N., Palmeri, A., Arancio, O., Conti, F., Grassi, C. and Puzzo, D. (2019) Neuromodulatory Action of Picomolar Extracellular A $\beta 42$ Oligomers on Presynaptic and Postsynaptic Mechanisms Underlying Synaptic Function and Memory. Journal of Neurosciences, 39, 5986-6000. https://doi.org/10.1523/JNEUROSCI.0163-19.2019

[12] Kucheryavykh, L.Y., Kucheryavykh, Y.V., Washington, A.V. and Inyushin, M.Y. (2018) Amyloid Beta Peptide Is Released during Thrombosis in the Skin. International Journal of Molecular Sciences, 19, 1705. https://doi.org/10.3390/ijms19061705

[13] Giorgetti, S., Raimondi, S., Pagano, K., Relini, A., Bucciantini, M., Corazza, A., Fogolari, F., Codutti, L., Salmona, M., Mangione, P., Colombo, L., De Luigi, A., Porcari, R., Gliozzi, A., Stefani, M., Esposito, G., Bellotti, V. and Stoppini, M. (2011) Effect of Tetracyclines on the Dynamics and Destruction of Beta2-Microglobulin Amyloid Fibrils. Journal of Biological Chemistry, 286, 2121-2131. https://doi.org/10.1074/jbc.M110.178376

[14] Cao, Y. and Mezzenga, R. (2019) Food Protein Amyloid Fibrils: Origin, Structure, Formation, Characterization, Applications and Health Implications. Advances in Colloid and Interface Science, 269, 334-356.

https://doi.org/10.1016/j.cis.2019.05.002

[15] Hernandez, C.M., Kayed, R., Zheng, H., Sweatt, J.D. and Dineley, K.T. (2010) Loss of alpha7 Nicotinic Receptors Enhances Beta-Amyloid Oligomer Accumulation, Exacerbating Early-Stage Cognitive Decline and Septohippocampal Pathology in a Mouse Model of Alzheimer's Disease. Journal of Neurosciences, 30, 2442-2453. https://doi.org/10.1523/JNEUROSCI.5038-09.2010

[16] De Felice, F.G., Vieira, M.N., Bomfim, T.R., Decker, H., Velasco, P.T., Lambert, M.P., Viola, K.L., Zhao, W.Q., Ferreira, S.T. and Klein, W.L. (2009) Protection of Synsapses against Alzheimer's-Linked Toxins: Insulin Signaling Prevents the Pathogenic Binding of A $\beta$ Oligomers. Proceedings of the National Academy of Sciences of the USA, 106, 1971-1976. https://doi.org/10.1073/pnas.0809158106

[17] Irwin, R.W. and Brinton, R.D. (2014) Allopregnanolone as Regenerative Therapeutic for Alzheimer's Disease: Translational Development and Clinical Promise. Progress in Neurobiology, 113, 40-55.

https://doi.org/10.1016/j.pneurobio.2013.08.004 
[18] Aghsami, M., Sharifzadeh, M., Sepand, M.R., Yazdankhah, M., Seyednejad, S.A. and Pourahmad, J. (2018) A cAMP Analog Attenuates Beta-Amyloid (1-42)-Induced Mitochondrial Dysfunction and Spatial Learning and Memory Deficits. Brain Research Bulletin, 140, 34-42. https://doi.org/10.1016/j.brainresbull.2018.03.016

[19] Palmeri, A., Ricciarelli, R., Gulisano, W., Rivera, D., Rebosio, C., Calcagno, E., Tropea, M.R., Conti, S., Das, U., Roy, S., Pronzato, M.A., Arancio, O., Fedele, E. and Puzzo, D. (2017) Amyloid- $\beta$ Peptide Is Needed for cGMP-Induced Long-Term Potentiation and Memory. Journal of Neurosciences, 37, 6926-6937.

https://doi.org/10.1523/JNEUROSCI.3607-16.2017

[20] Ugarte, A., Gil-Bea, F., Garcia-Barroso, C., Cedazo-Minguez, A., Ramirez, M.J., Franco, R., Garcia-Osta, A., Oyarzabal, J. and Cuadro-Tejedor, M. (2015) Decreased Levels of Guanosine 3', 5'-Monophosphate (cGMP) in Cerebrospinal Fluid (CSF) Are Associated with Cognitive Decline and Amyloid Pathology in Alzheimers's Disease. Neuropathology and Applied Neurobiology, 41, 471-482.

https://doi.org/10.1111/nan.12203

[21] Hesse, R., Lausser, L., Gummert, P., Schmid, F., Wahler, A., Schnack, C., Kroker, K.S., Otto, M., Tumani, H., Kestler, H.A., Rosenbrock, H. and von Arnim, C.A.F. (2017) Reduced cGMP Levels in CSF of AD Patients Correlate with Severity of Dementia and Current Depression. Alzheimer's Research and Therapy, 9, Article No. 17. https://doi.org/10.1186/s13195-017-0245-y

[22] Yang, F., Lim, G.P., Begum, A.N., Ubeda, O.J., Simmons, M.R., Ambegaokar, S.S., Chen, P.P., Kayed, R., Giabe, C.G., Frautschy, S.A. and Cole, G.M. (2005) Curcumin Inhibits Formation of Amyloid Beta Oligomers and Fibrils, Binds Plaques, and Reduces Amyloid in Vivo. Journal of Biological Chemistry, 18, 5892-5901.

https://doi.org/10.1074/jbc.M404751200

[23] Jiang, P., Li, W., Shea, J.E. and Mu, Y. (2011) Resveratrol Inhibits the Formation of Multiple-Layered $\beta$-Sheet Oligomers of the Human Islet Amyloid Polypeptide Segment 22-27. Biophysics Journal, 100, 1550-1558.

https://doi.org/10.1016/j.bpj.2011.02.010

[24] Zurita, M.P., Munoz, G., Sepulveda, F.J., Gomez, P., Castillo, C., Burgos, C.F., Fuentealba, J., Opazo, C. and Aguayo, L.G. (2013) Ibuprofen Inhibits the Synaptic Failure Induced by the Amyloid- $\beta$ Peptide in Hippocampal Neurons. Journal of Alzheimer's Disease, 35, 463-473. https://doi.org/10.3233/JAD-122314

[25] Diaz, J.C., Simakova, O., Jacobson, K.A., Arispe, N. and Pollard, H.B. (2009) Small Molecule Blockers of the Alzheimer A $\beta$ Calcium Channel Potently Protect Neurons from A $\beta$ Cytotoxicity. Proceedings of the National Academy of Sciences of the USA, 106, 3348-3353. https://doi.org/10.1073/pnas.0813355106

[26] Zhao, L., Zhu, L. and Guo, X. (2018) Valproic Acid Attenuates A $\beta_{25-35}$-Induced Neurotoxicity in PC12 Cells through Suppression of Mitochondria-Mediated Apoptotic Pathway. Biomedicine and Pharmacotherapy, 106, 77-82. https://doi.org/10.1016/j.biopha.2018.06.080

[27] Emamghoreishi, M., Farrokhi, M.R., Amiri, A. and Keshavarz, M. (2019) The Neuroprotective Mechanism of Cinnamaldehyde against Amyloid- $\beta$ in Neuronal SHSY5Y Cell Line: The Role of N-methyl-D-aspartate, Ryanodine, and Adenosine Receptors and Glycogen Synthase Kinase-3 $\beta$. Avicenna Journal of Phytomedicine, 9, 271-280.

[28] Huang, X., Zhen, J., Dong, S., Zhang, H., Van Halm-Lutterodt, N. and Yuan, L. (2019) DHA and Vitamin E Antagonized the $A \beta_{25-35}$-Mediated Neuron Oxidative Damage through Activation of Nrf2 Signaling Pathways and Regulation of CD36, SRB1 and FABP5 Expression in PC12 Cells. Food and Function, 10, 1049-1061. https://doi.org/10.1039/C8FO01713A 
[29] Yu, M., Chen, X., Liu, J., Ma, Q., Zhuo, Z., Chen, H., Zhou, L., Yang, S., Zheng, L., Ning, C., Xu, J., Gao, T. and Hou, S.T. (2019) Gallic Acid Disruption of A $\beta_{1-42}$ Aggregation Rescues Cognitive Decline of APP/PS1 Double Transgenic Mouse. Neurobiology of Disease, 124, 67-80. https://doi.org/10.1016/j.nbd.2018.11.009

[30] Florent, S., Malaplate-Armand, C., Youssef, L., Kriem, B., Koziel, V., Escanye, M.C., Fifre, A., Sponne, L., Leininger-Muller, B., Olivier, J.L., Pillot, T. and Oster, T. (2006) Docosahexaenoic Acid Prevents Neuronal Apoptosis Induced by Soluble Amyloid-Beta Oligomers. Journal of Neurochemistry, 96, 385-395.

https://doi.org/10.1111/j.1471-4159.2005.03541.x

[31] Yu, H.L., Li, L., Zhang, X.H., Xiang, L., Zhang, J., Feng, J.F. and Xiao, R. (2009) Neuroprotective Effects of Genistein and Folic Acid on Apoptosis of Rat Cultured Cortical Neurons Induced by Beta-Amyloid 31-35. British Journal of Nutrition, 102, 655-662. https://doi.org/10.1017/S0007114509243042

[32] Heneka, M.T., Kummer, M.P., Weggen, B., Bulic, G., Multhaup, L., Munter, M., Hunt, T., Pflanzner, T. and Pietrzik, C.U. (2011) Molecular Mechanisms and Therapeutic Applications of NSAIDs and Derived Compounds in Alzheimers Disease. Current Alzheimer Research, 8, 115-131. https://doi.org/10.2174/156720511795256099

[33] Williams, W.R. (2020) Tumour Initiation, Store-Operated Calcium Entry (SOCE) and Apoptosis: Cyclic Nucleotide Dependence. General Physiology and Biophysics, 39, 419-435. https://doi.org/10.4149/gpb 2020020

[34] Song, Y., Li, P., Liu, L., Bortolini, C. and Dong, M. (2018) Nanostructural Differentiation and Toxicity of Amyloid- $\beta_{25-35}$ Aggregates Ensue from Distinct Secondary Conformation. Scientific Reports, 8, Article No. 765. https://doi.org/10.1038/s41598-017-19106-y

[35] Cummings, J., Lee, G., Ritter, A., Sabbagh, M. and Zhong, K. (2019) Alzheimer's Disease Drug Development Pipeline: 2019. Alzheimer's and Dementia, 5, 272-293. https://doi.org/10.1016/j.trci.2019.05.008

[36] Xu, J., Zhou, L., Weng, Q., Xiao, L. and Li, Q. (2019) Curcumin Analogues Attenuate $\mathrm{AB}_{25-35}$-Induced Oxidative Stress in PC12 Cells via Keap 1/Nrf2/HO-1-Signaling Pathways. Chemico-Biological Interactions, 305, 171-179. https://doi.org/10.1016/j.cbi.2019.01.010

[37] Yang, J., Sun, Y., Xu, F., Liu, W., Hayashi, T., Hattori, S., Ushiki-Kaku, Y., Onodera, S., Tashiro, S.I. and Ikejima, T. (2019) Silibinin Protects Rat Pancreatic $\beta$-Cell through Up-Regulation of Estrogen Receptors' Signaling against Amylin- or A $\beta_{1-42}$-Induced Reactive Oxygen Species/Reactive Nitrogen Species Generation. Phytotherapy Research, 33, 998-1009. https://doi.org/10.1002/ptr.6293

[38] Monfort, P. and Felipo, V. (2010) Amyloid- $\beta$ Impairs, and Ibuprofen Restores, the cGMP Pathway, Synaptic Expression of AMPA Receptors and Long-Term Potentiation in the Hippocampus. Journal of Alzheimer's Disease, 22, 795-809. https://doi.org/10.3233/JAD-2010-101092

[39] Akan, P., Kizildag, S., Ormen, M., Genc, S., Oktem, M.A. and Fadiloglu, M. (2009) Pregnenolone Protects the PC-12 Cell Line against Amyloid Beta Peptide Toxicity but Its Sulphate Ester Does Not. Chemico-Biological Interactions, 177, 65-70. https://doi.org/10.1016/j.cbi.2008.09.016

[40] Bitar, F.E., Meunier, J., Villard, V., Almeras, M., Krishnan, K., Covey, D.F, Maurice, T. and Akwa, Y. (2014) Neuroprotection by the Synthetic Neurosteroid Enantiomers ent-PREGS and ent-DHEAS against $\mathrm{A} \beta_{25-35}$ Peptide-Induced Toxicity in Vitro and in Vivo in Mice. Psychopharmacology (Berl), 231, 3293-3312.

https://doi.org/10.1007/s00213-014-3435-3 
[41] Tonnies, E. and Trushina, E. (2017) Oxidative Stress, Synaptic Dysfunction, and Alzheimer's Disease. Journal of Alzheimer's Disease, 57, 1105-1121. https://doi.org/10.3233/JAD-161088

[42] Kelly, M.P. (2018) Cyclic Nucleotide Signaling Changes Associated with Normal Aging and Age-Related Diseases of the Brain. Cellular Signalling, 42, 281-291. https://doi.org/10.1016/j.cellsig.2017.11.004

[43] Chen, X. and Yan, S.D, (2006) Mitochondrial A $\beta$ : A Potential Cause of Metabolic Dysfunction in Alzheimer's Disease. IUBMB Life, 58, 686-694. https://doi.org/10.1080/15216540601047767

[44] Ghasemi, M., Mayasi, Y., Hannoun, A., Esiami, S.M. and Carandang, R. (2018) Nitric Oxide and Mitochondrial Function in Neurological Diseases. Neuroscience, 376, 48-71. https://doi.org/10.1016/j.neuroscience.2018.02.017

[45] Zeeshan, H.M.A., Lee, G.H., Kim, H.R. and Chae, H.J. (2016) Endoplasmic Reticulum Stress and Associated ROS. International Journal of Molecular Sciences, 17, 327. https://doi.org/10.3390/ijms17030327

[46] Liu, P.Z. and Nusslock, R. (2018) Exercise-Mediated Neurogenesis in the Hippocampus via BDNF. Frontiers in Neuroscience, 12, 52.

https://doi.org/10.3389/fnins.2018.00052

[47] Jia, R.X., Liang, J.H., Xu, Y. and Wang, Y.Q. (2019) Effects of Physical Exercise on the Cognitive Function of Patients with Alzheimer Disease: A Meta-Analysis. BMC Geriatrics, 19, Article No. 181. https://doi.org/10.1186/s12877-019-1175-2

[48] Tampellini, D., Rahman, N., Gallo, E.F., Huang, Z., Magali, D., Capetillo-Zarato, E., Ma, T., Zheng, R., Lu, B., Nanus, D.M., Lin, M.T. and Gouras, G.K. (2009) Synaptic Activity Reduces Intraneuronal A $\beta$, Promotes APP Transport and Protects against A $\beta$-Related Synaptic Alterations. Journal of Neurosciences, 29, 9704-9713. https://doi.org/10.1523/JNEUROSCI.2292-09.2009

[49] Jurgensen, S., Antonio, L.L., Mussi, G.E.A., Brito-Moreira, J., Bomfim, T.R., De Felice, F.G., Garrido-Sanabria, E.R., Cavalheiro, E.A. and Ferreira, S.T. (2011) Activation of D1/D5 Dopamine Receptors Protects Neurons from Synapse Dysfunction Induced by Amyloid- $\beta$ Oligomers. Journal of Biological Chemistry, 286, 3270-3276. https://doi.org/10.1074/jbc.M110.177790

[50] Peters, C., Sepulveda, F.J., Fernandez-Perez, E.J., Peoples, R.W. and Aguayo, L.G. (2016) The Level of NMDA Receptor in the Membrane Modulates Amyloid- $\beta$ Association and Perforation. Journal of Alzheimer's Disease, 53, 197-207. https://doi.org/10.3233/JAD-160170

[51] D’Andrea, M.R. and Nagele, R.G. (2006) Targeting the Alpha 7 Nicotinic Acetylcholine Receptor to Reduce Amyloid Accumulation in Alzheimer's Disease Pyramidal Neurons. Current Pharmacological Design, 12, 677-684.

https://doi.org/10.2174/138161206775474224 